\title{
Paleoceanography
}

\section{RESEARCH ARTICLE \\ 10.1002/2014PA002665 \\ Exceptional Agulhas leakage prolonged interglacial warmth during MIS 11c in Europe}

Key Points:

- Persistent warmth across Europe beyond the MIS 11c climate optimum

- Exceptionally strong Agulhas leakage at the end of MIS 11C

- Agulhas leakage/AMOC

interhemispheric teleconnection prolonged MIS 11c warmth

Supporting Information:

- Figure S1 and Tables S1 and S2

Correspondence to:

A. Koutsodendris,

andreas.koutsodendris@geow.uni-

heidelberg.de

\section{Citation:}

Koutsodendris, A., J. Pross, and R. Zahn (2014), Exceptional Agulhas leakage prolonged interglacial warmth during MIS 11c in Europe, Paleoceanography, 29, 1062-1071, doi:10.1002/ 2014 PA002665.

Received 5 MAY 2014 Accepted 14 OCT 2014 Accepted article online 17 OCT 2014 Published online 12 NOV 2014

\author{
Andreas Koutsodendris ${ }^{1}$, Jörg Pross' ${ }^{1}$, and Rainer Zahn ${ }^{2}$ \\ ${ }^{1}$ Paleoenvironmental Dynamics Group, Institute of Earth Sciences, University of Heidelberg, Heidelberg, Germany, \\ ${ }^{2}$ Institució Catalana de Recerca i Estudis Avançats (ICREA), Institut de Ciència i Tecnologia Ambientals (ICTA), Departament \\ de Física, Universitat Autònoma de Barcelona, Barcelona, Spain
}

Abstract The transport of warm and saline surface water from the Indo-Pacific Ocean into the South Atlantic ("Agulhas leakage") influences the Atlantic Meridional Overturning Circulation (AMOC), which in turn exerts control on European climate. Paleoceanographic data document a remarkably strong Agulhas leakage at the end of marine isotope stage (MIS) $11 \mathrm{c}$ interglacial ( 400 ka B.P.), which is one of the best orbital analogues for the Holocene. Here we assess the potential influence of this exceptional Agulhas leakage on North Atlantic climate based on a compilation of marine and terrestrial proxy records from the lberian margin and continental Europe. We show that a $\sim 5$ ka long warm period persisted across Europe beyond the MIS 11c climatic optimum. This warm period is testified by increases in foraminifer-derived sea surface temperatures on the Iberian margin, a spread of temperate trees on Iberia, and the expansion both of evergreen trees and thermophilous diatom taxa in Central European lowlands. Paradoxically, this warming coincides with an insolation minimum, implying that orbital forcing can be excluded as the underlying cause. We conclude that persistent warmth during weak insolation at the end of MIS 11c in Europe may have been triggered by strengthened Agulhas leakage, which stimulated a vigorous AMOC and increased the northward transport of warm surface waters to higher latitudes via the North Atlantic Current. The close analogy of the present and MIS 11c orbital forcing underlines the possibility that the present-day increase of the Agulhas leakage, although driven by different forcing than MIS 11c, may considerably affect future climates across Europe.

\section{Introduction}

The Agulhas Current transports warm and saline surface water from the Indo-Pacific Ocean into the South Atlantic, thereby impacting the density budget of the Atlantic Ocean and influencing the Atlantic Meridional Overturning Circulation (AMOC) [Lutjeharms, 2006; Biastoch et al., 2008]. Instrumental [Rouault et al., 2009; Backeberg et al., 2012] and paleoceanographic data [Peeters et al., 2004; Martínez-Méndez et al., 2010; Caley et al., 2012; Marino et al., 2013] as well as modeling studies [Biastoch et al., 2008; van Sebille et al., 2010] show that this process, known as "Agulhas leakage," peaks on decadal to millennial time scales. Notably, on orbital (i.e., glacialinterglacial) time scales the strength of the Agulhas leakage went along with latitudinal shifts of the oceanic Subtropical Front (STF) south of Africa [Peeters et al., 2004; Cortese et al., 2007; Bard and Rickaby, 2009]. Migrations of the STF follow shifts in the prevailing westerly winds that fostered transient Agulhas leakage changes, thereby modulating the strength of the $\mathrm{AMOC}$ and triggering its resumption to full strength during glacial terminations [Peeters et al., 2004; Caley et al., 2012]. By extension, the southerly position of the STF may be key to support a sustained influence of Agulhas leakage on keeping the AMOC in its strong interglacial mode.

The Agulhas leakage ultimately influences the Gulf Stream and North Atlantic Current (NAC) [Beal et al., 2011], which in turn exerts control on European climate via its easterly branches, i.e., the Azores and Portugal Currents (Figure 1) [Naughton et al., 2007; Voelker and de Abreu, 2011]. Although there is increasing evidence that Agulhas leakage affects the strength of the AMOC, the strength of the connection between them is beyond direct observations [Beal et al., 2011]. As a consequence, the impact of Agulhas leakage on climate in the North Atlantic region is yet poorly constrained. This holds particularly true for Western Europe, although this region is a sensitive recorder of $A M O C$ variability due to its direct downstream position with regard to the northward marine heat transport that characterizes the North Atlantic.

We here compile evidence from previously published proxy records off the Iberian margin, a region that is critical for understanding the coupling between marine (i.e., North Atlantic) and terrestrial (i.e., continental European) components of the climate system [Martrat et al., 2007], and from Central Europe that make a 


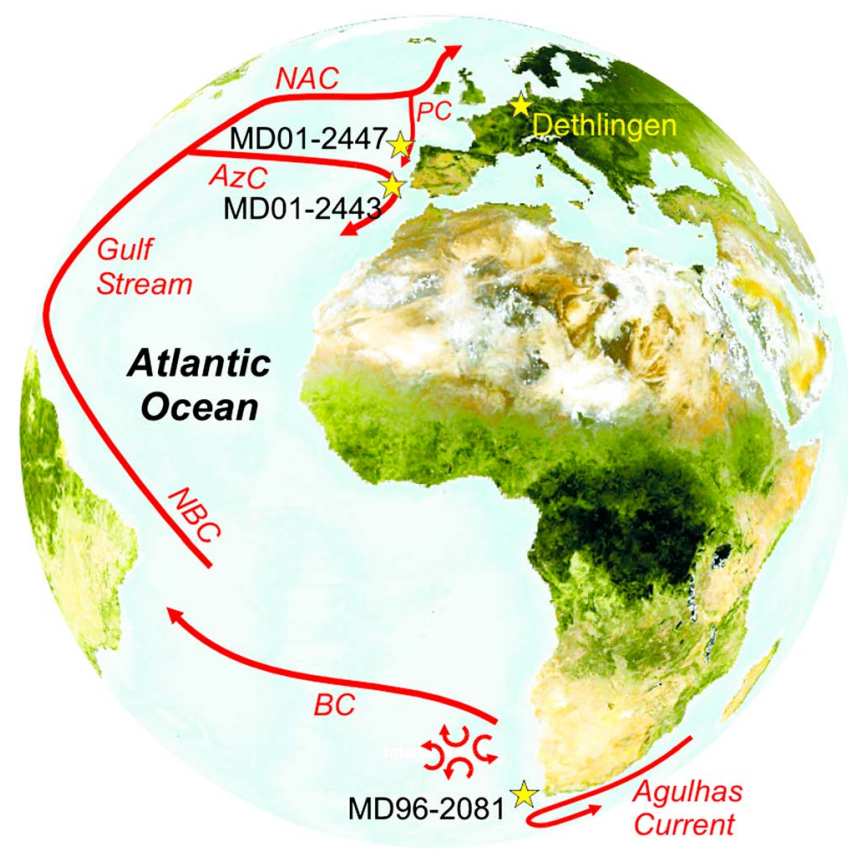

Figure 1. Locations of sites discussed in the text and major surface currents of the Atlantic Ocean circulation. AzC: Azores Current; BC: Benguela Current; NAC: North Atlantic Current: NBC: North Brazil Current; and PC: Portugal Current. strong case for anomalous warmth in Europe at the end of MIS 11c (Figure 1). Paleoceanographic records from the southern tip of Africa show a period of enhanced Agulhas leakage at that time, which opens the possibility that an interhemispheric teleconnection existed between the Agulhas leakage in the South Atlantic and AMOC-driven warmth in Europe $\sim 400 \mathrm{ka}$ ago.

\subsection{Marine Isotope Stage 11c Climate Records}

Representing one of the best paleoclimatic analogues for the Holocene interglacial [Loutre and Berger, 2003], MIS 11c is particularly well suited to investigate the natural response of climate to increased Agulhas leakage and its consequences for terrestrial ecosystems as they may also occur in the near future [Müller and Pross, 2007; Tzedakis, 2010]. A unique feature of the Agulhas leakage during MIS 11c merits special attention. Based on indicator foraminiferal taxa that allow to trace the interoceanic exchange in the SE Atlantic, Agulhas leakage appears to have strengthened twice during MIS 11c [Peeters et al., 2004]. A first peak occurred during Termination V (i.e., the onset of MIS 11c), as it is the case for all glacial terminations of the past $1 \mathrm{Ma}$ [Caley et al., 2012]. Exceptionally, a second leakage peak occurred at the end of the MIS 11c (400-398 ka B.P.); notably, this distinct peak occurred during an insolation minimum centered at $398 \mathrm{ka}$ ago (Figures $2 \mathrm{a}$ and $2 \mathrm{~d}$ ). It has been hypothesized that this second Agulhas leakage peak positively feedback on the AMOC by strengthening the overturning circulation at the end of MIS $11 \mathrm{c}$, thus possibly supplying extra warmth and moisture to the Northern Hemisphere [Dickson et al., 2010a, 2010b] at a time when global climate developed progressively toward cold glacial conditions. If correct, the enhanced poleward transport of marine heat to the North Atlantic region should be expressed both in marine and terrestrial proxy data by anomalously increased temperatures and marked ecosystem responses.

To test this hypothesis, we here evaluate previously published records from (i) the Iberian margin, as it represents the only setting in the North Atlantic for which robust land-sea correlations for MIS 11c have been established [e.g., Desprat et al., 2005; Martrat et al., 2007; Tzedakis et al., 2009; Voelker and de Abreu, 2011] and (ii) the Dethlingen paleolake in the Central European lowlands, as it comprises the only highly resolved (i.e., seasonal to subdecadal scales) multiproxy paleoclimate record for MIS 11c from continental Europe [Koutsodendris et al., 2010, 2011, 2013].

\section{Methods}

We compare the Agulhas leakage fauna (ALF) index (i.e., a sum of typical tropical and subtropical planktic foraminifera used as an indicator of the Agulhas leakage strength) from core MD96-2081 (Cape Basin; $35^{\circ} 35^{\prime} \mathrm{S}$, $17^{\circ} 41^{\prime} \mathrm{E}$; Figure 1) [Peeters et al., 2004] with marine and terrestrial climate signals from the lberian margin. These climate signals comprise (i) sea surface temperature (SST) reconstructions based on planktic foraminiferal assemblages using a modern analogue technique [de Abreu et al., 2005] and based on alkenones [Martrat et al., 2007] from core MD01-2443 $\left(37^{\circ} 52.85^{\prime} \mathrm{N}, 10^{\circ} 10.57^{\prime} \mathrm{W}\right.$; Figures 1 and 2e-2f); and (ii) pollen data from cores MD01-2443 [Tzedakis et al., 2009] and MD01-2447 [Desprat et al., 2005] (42 $09^{\prime} \mathrm{N}$, $09^{\circ} 40^{\prime} \mathrm{W}$; Figures 1, $2 \mathrm{~g}$, and $2 \mathrm{~h}$ ). To further constrain the potential impact of Agulhas leakage on continental climate in Europe, we augment our study with terrestrial proxy data from Central Europe. For that region, 


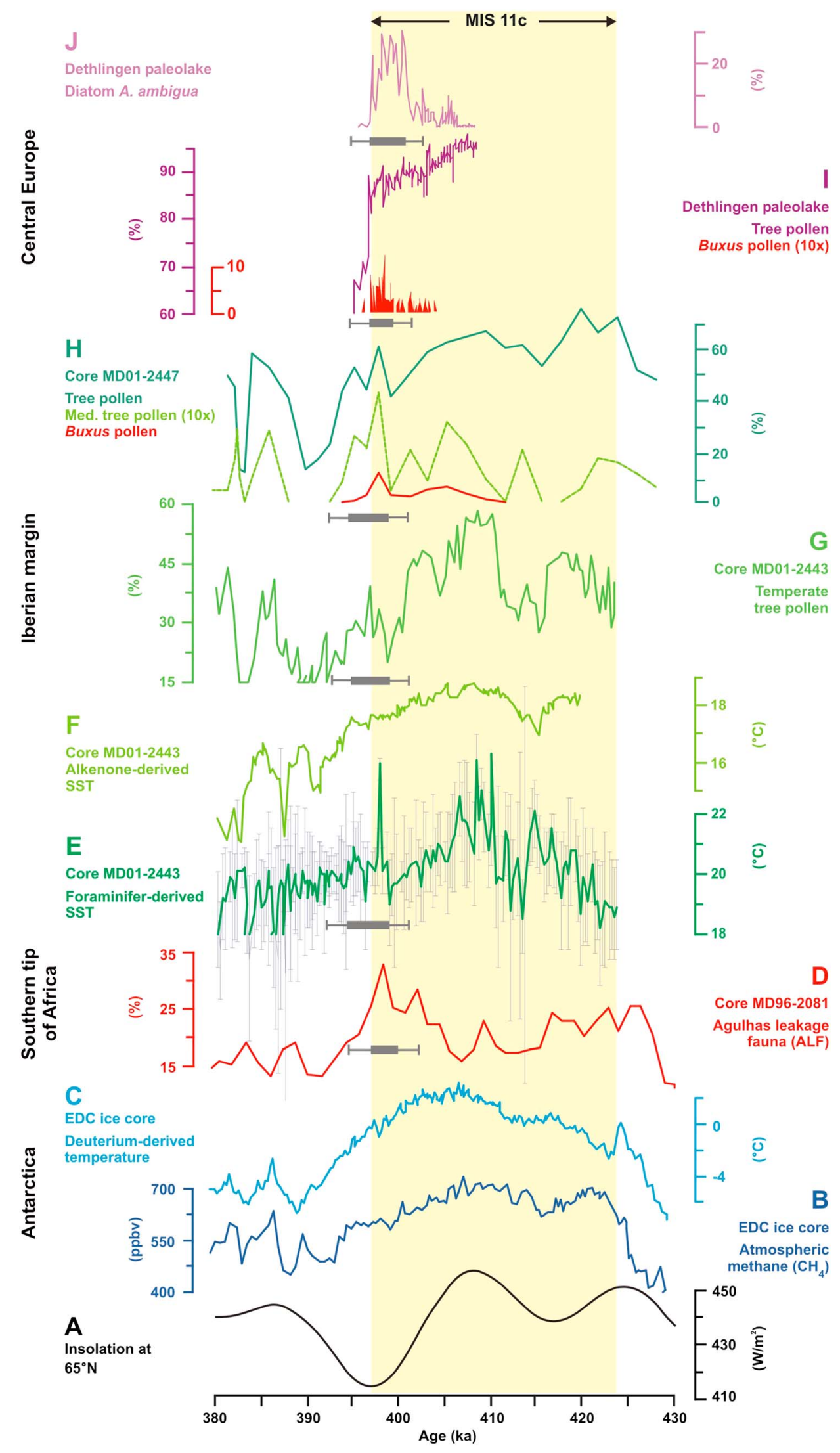

Figure 2 
Table 1. Tie Points Used to Correlate the Pollen Record From Core MD96-2081 to the LR04 Benthic $\delta^{18}$ O Stack [Lisiecki and Raymo, 2005]

\begin{tabular}{|c|c|c|c|}
\hline \multirow[b]{2}{*}{ LR04 (ka) } & MD96-2081 (cmbsf) & \multirow[b]{2}{*}{ LR04 (ka) } & \multirow{2}{*}{$\frac{\text { MD96-2081 (cmbsf) }}{\delta^{18} \text { O Midpoints }}$} \\
\hline & $\delta^{18} \mathrm{O}$ Minima/Maxima & & \\
\hline 341 & 1363 & 335.5 & 1324 \\
\hline 397 & 1568 & 396.5 & 1567 \\
\hline 431 & 1708 & 421.2 & 1685 \\
\hline 491 & 1853 & 483.5 & 1825 \\
\hline
\end{tabular}

${ }^{\mathrm{a}} \mathrm{cmbsf}=$ centimeters below sea floor.

the Holsteinian interglacial is the terrestrial equivalent of MIS 11c as evidenced by direct palynological land-sea [Desprat et al., 2005] and regional biostratigraphic and lithostratigraphic correlations [de Beaulieu et al., 2001; Preece et al., 2007]. Based on this notion, we here reevaluate previously published, decadal-scale-resolution pollen and diatom data from partially varved lake sediments from Dethlingen (Germany; Figures 1, 2i, and 2j), which sensitively record abrupt climate change during the climatic optimum of MIS 11c [Koutsodendris et al., 2010, 2013].

\subsection{Development of Age Models}

A comparison of proxy records from the North and South Atlantic critically hinges upon the availability of consistent, high-quality age models. Previous attempts to correlate $\delta^{18} \mathrm{O}$ records from the North and South Atlantic spanning the entire MIS 11 interval (330-430 kyr B.P.) were based on graphical tuning to the European Project for Ice Coring in Antarctica (EPICA) Dome C (EDC3) time scale [Parrenin et al., 2007]. This yielded robust age models with small temporal offsets ( 2.1 ka on average) [Vázquez Riveiros et al., 2013]. Given that the age difference between the LR04 $\delta^{18}$ O benthic stack [Lisiecki and Raymo, 2005], which is commonly used for tuning of marine records, and the EDC3 time scale for the studied interval is only 400 years [Parrenin et al., 2007], we here tuned the ALF from core MD96-2081 [Peeters et al., 2004] to the LR04 stack. This approach facilitates a further comparison, with only minor age uncertainties, of the AFL record with other proxy records from the Atlantic Ocean. In particular, the chronology of the ALF record was derived by placing the Cibicides wuellerstorfi $\delta^{18} \mathrm{O}$ record of core MD96-2081 on the LR04 benthic $\delta^{18} \mathrm{O}$ stack employing two different methodologies (Table 1 and Figure 3): (a) aligning $\delta^{18} \mathrm{O}$ minima and maxima of the two records using the tie points of Dickson et al. [2010b], (b) aligning $\delta^{18} \mathrm{O}$ midpoints (glacial/interglacial transitions) between MIS 10 and MIS 12 using the "AnalySeries 2.0" software [Paillard et al., 1996]. The two chronologies for the ALF record deviate from each other for the onset of MIS 11c and the later MIS 11 substages (i.e., MIS $11 \mathrm{a}$ and MIS $11 \mathrm{~b}$ ) by $\sim 2 \mathrm{ka}$. However, there is no considerable difference during the second ALF peak ( 400 ka B.P.; Figure 4), which is the interval this study focuses on. Hence, we here use the tie points of Dickson et al. [2010b] to develop the chronology for the ALF record during MIS 11c in order to facilitate comparisons with previously published records.

In addition, core MD01-2447 [Desprat et al., 2005] was aligned to core MD01-2443, which is plotted on the EDC3 time scale [Tzedakis et al., 2009] by aligning prominent minima in temperate tree pollen percentages

Figure 2. Compilation of well-dated proxy records spanning MIS 11c ( 398-425 ka B.P.; colored box). (a) Insolation at $65^{\circ} \mathrm{N}$ [Berger and Loutre, 1991]; (b) global atmospheric methane $\left(\mathrm{CH}_{4}\right)$ concentrations [Loulergue et al., 2008], and (c) deuteriumderived Antarctic temperature reconstruction [Jouzel et al., 2007] from the EPICA Dome C (EDC) ice core; (d) Agulhas leakage fauna (ALF) percentages in core MD96-2081 as an indicator for Agulhas leakage strength around the southern tip of Africa [Peeters et al., 2004]; (e) foraminifer-derived summer sea surface temperature [de Abreu et al., 2005] and (f) alkenone-derived sea surface temperature (maximum error $0.5^{\circ} \mathrm{C}$ ) [Martrat et al., 2007] measured on core MD01-2443 as indicators for warm surface water conditions off Iberia; (g) temperate tree pollen percentages from core MD01-2443 [Tzedakis et al., 2009] and (h) total tree (excluding Pinus), Mediterranean taxa (10X; dashed line) and Buxus pollen percentages from core MD01-2447 [Desprat et al., 2005] representing interglacial vegetation dynamics on the lberia peninsula; (i) total tree and Buxus (10X) pollen percentages, and (j) planktic diatom Aulacoseira ambigua percentages from the Dethlingen paleolake sediments portraying interglacial vegetation dynamics [Koutsodendris et al., 2010] and aquatic conditions [Koutsodendris et al., 2013], respectively, in the Central European lowlands. Gray bars below proxy records indicate the warm interval at the end of MIS 11c; error bars show age model uncertainties of $\sim 2$ ka between South and North Atlantic records [Vázquez Riveiros et al., 2013]. 
Depth (mbsf)

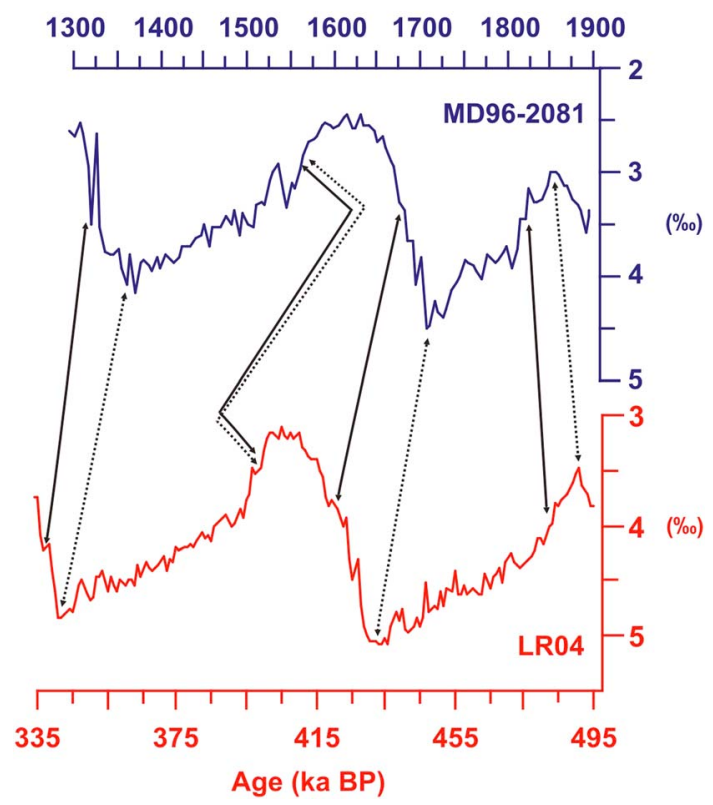

Figure 3. Tuning of $\delta^{18} \mathrm{O}$ benthic record from core MD962081 [Peeters et al., 2004] to the LR04 $\delta^{18}$ O stack [Lisiecki and Raymo, 2005]. Dashed lines indicate the tie points of Dickson et al. [2010b], whereas solid lines indicate the midpoints employed here (see also Figure 3 ) for the alternative alignment of the two records (see Table 1 for alternative tie points). $\mathrm{mbsf}=$ meters below sea floor. between 380 and 420 ka B.P. (Table 2 and Figure 5). Finally, we used the insolation minimum at 398 ka B.P., which is widely considered to have terminated the MIS 11c interglacial [Martrat et al., 2007; Müller and Pross, 2007; Tzedakis et al., 2012], as a tie point for the glacial inception at Dethlingen that is inferred from the collapse of tree pollen percentages (Figure 2i).

\section{Results and Discussion}

\subsection{Evidence for Persistent Warmth at the End} of MIS 11c in Europe

The SST reconstructions and the trends in temperate tree pollen percentages from cores MD01-2443 and MD01-2447 (Figures 2e-2h) demonstrate a close correspondence with global methane $\left(\mathrm{CH}_{4}\right)$ concentrations (Figure $2 \mathrm{~b}$ ) [Loulergue et al., 2008] and Antarctic temperature variability (Figure 2c) [Jouzel et al., 2007] during MIS 11c [Tzedakis et al., 2009]. Although the coherence between the $\mathrm{CH}_{4}$ and the pollen records suggests concurrent changes in the continental hydrological balance and hence an influence of global climatic developments, the warming recorded in the marine paleoclimate data off Iberia at the end of the MIS 11c ( 400-395 ka B.P.) has no direct equivalent in Antarctic ice-core profiles.

In particular, the orbitally forced foraminifer-derived SST decline during the second part of MIS 11c ( $\sim 408-400$ ka B.P.) is interrupted by a transient, $\sim 5$ ka long phase of higher temperatures and similar to the mean Holocene SST in this region $\left(\sim 20-21^{\circ} \mathrm{C}\right)$ [de Abreu et al., 2005] that occurred during the insolation minimum (Figure 2e). This phase is associated with a higher abundance of (sub)tropical planktic foraminifera (e.g., Globigerinoides ruber, Orbulina universa, and Globoturborotalita rubescens) in core MD01-2443 [de Abreu et al., 2005] and a coeval increase of an identical fauna at the end of MIS 11c in core MD01-2447 [Desprat et al., 2005]. These observations consistently point to a $\sim 5 \mathrm{ka}$ long buildup of marine warmth off lberia. This prolonged warmth is in agreement with alkenone data indicating that surface water temperatures off lberia remained conspicuously high at the end of MIS 11c [Martrat et al., 2007; Rodrigues et al., 2011]; in particular,

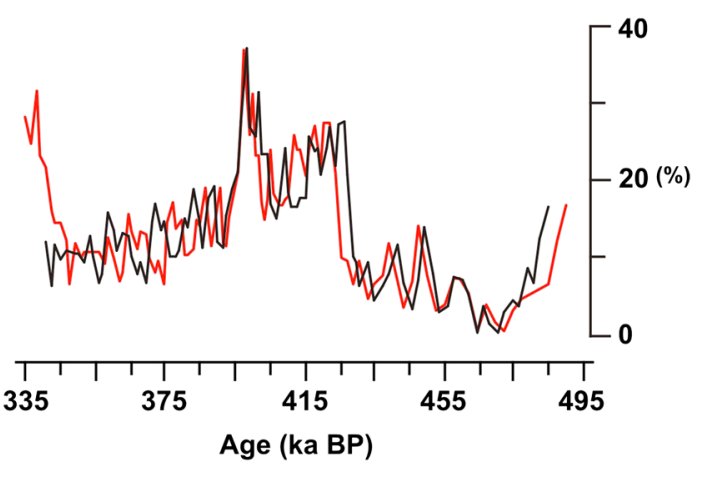

Figure 4. Alternative age models for the Agulhas leakage fauna (ALF) record (core MD96-2081) [Peeters et al., 2004] spanning MIS 10-12 (a) using the tie points of Dickson et al. [2010b] (black line) and (b) using midpoints of glacial/interglacial transitions (red line). these data show only a minimal longer-term cooling between 408 and 400 ka B.P., and document that warm surface water conditions prevailed during the insolation minimum (compare Figures $2 \mathrm{e}$ and $2 \mathrm{f}$ ). The fact that they do not show a true reversal in temperature development toward warmer conditions as documented in the foraminifer-based SST reconstructions from the same core between 399 and 395 ka B.P. may be attributed to differences in proxy sensitivity, notably the markedly different ecological responses of coccolithophores and planktic foraminifera to oceanographic conditions in winter and summer [e.g., Leduc et al., 2010; Schneider et al., 2010]. Additional support for the scenario of prolonged warmth off Iberia at the end of MIS 11c comes from coccolithophore assemblage data from core MD03-2669; they exhibit 
Table 2. Tie Points Used to Correlate the Pollen Records From Cores MD012447 [Desprat et al., 2005] and MD01-2443 [Tzedakis et al., 2009] During MIS 11C

\begin{tabular}{lc} 
MD01-2443 (ka) & MD01-2447 (mbsf) \\
\hline 381.40 & 40.20 \\
383.05 & 40.45 \\
389.77 & 40.80 \\
398.99 & 41.50 \\
415.52 & 42.30 \\
\hline
\end{tabular}

${ }^{a} \mathrm{mbsf}=$ meters below sea floor. high abundances of warm taxa during the insolation minimum [Palumbo et al., 2013].

Further evidence for climatic warming at the end of the MIS $11 \mathrm{c}$ is available from the terrestrial realm. The trends in temperate tree pollen percentages in both cores, i.e., MD012443 and MD01-2447, are strongly similar to the foraminifer-derived SST

trend (Figures $2 \mathrm{~g}$ and $2 \mathrm{~h}$ ): Following a long-term decline after the MIS 11c insolation maximum at $408 \mathrm{ka}$ B.P., temperate tree pollen percentages increase by $\sim 10-15 \%$ before the glacial inception, thus suggesting a recovery of temperate forests on lberia during the insolation minimum. The transient recovery of the temperate trees in core MD01-2447 falls within the general trend of declining deciduous Quercus pollen percentages, which has been interpreted to represent climate cooling [Desprat et al., 2005]. However, a closer inspection of the pollen assemblages reveals that the decline of Quercus percentages is coeval with increasing percentages of Abies, Ericaceae, and-to a lesser extent-Carpinus. These taxa typically expand during the oligocratic forest stages, which are associated with the impoverishment of soils late during interglacials rather than climate cooling [e.g., Birks, 1986; Birks and Birks, 2004; Wardle et al., 2004]. Even more interestingly, the pollen percentages of Mediterranean taxa (e.g., evergreen Quercus, Olea, and Phillyrea) increased during the insolation minimum, reaching a maximum of $4.3 \%$ in core MD01-2447 (Figure 2h) [Desprat et al., 2005] and almost 10\% in core MD01-2443 [Tzedakis et al., 2009]. The presence of these taxa suggests the prevalence of frost-free winters on Iberia [Fletcher et al., 2010] despite the weak insolation. Notably, this interval is marked by maximum percentages of Buxus (Figure 2h), which has important implications for deciphering paleoclimate dynamics across Europe. Because Buxus is insect pollinated and

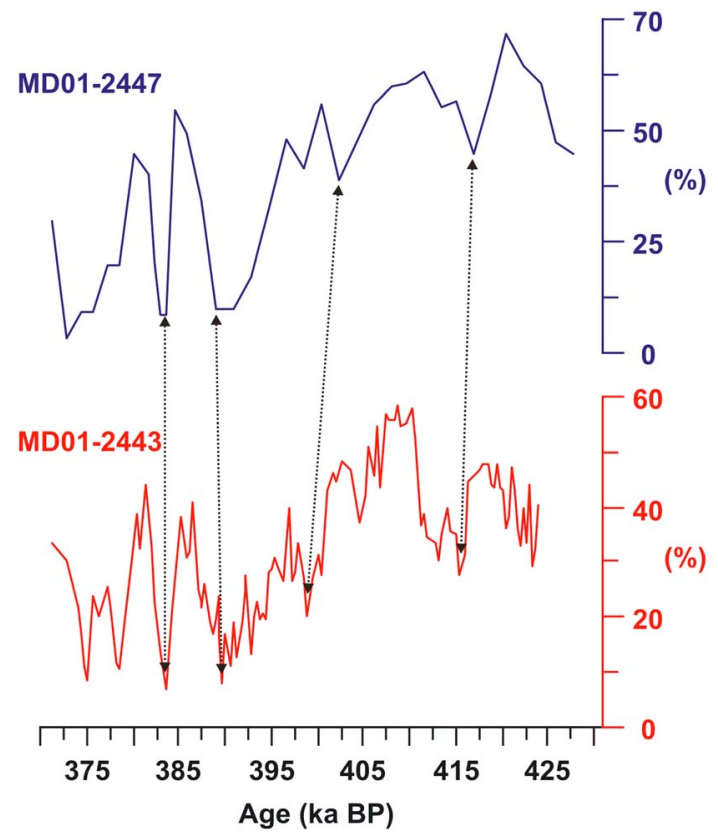

Figure 5. Pollen records from cores MD01-2443 [Tzedakis et al., 2009] and MD01-2447 [Desprat et al., 2005] spanning MIS 11c plotted against their previously published chronologies, which were tuned to the EDC3 [Parrenin et al., 2007] and low-latitude stack [Bassinot et al., 1994] time scales, respectively. Dashed arrows indicate the tie points used (Table 2) to align the two records. thus strongly underrepresented in pollen spectra, even small pollen concentrations of this taxon at a site testify to its local presence. Buxus grew in Central European lowlands during MIS 11c as documented by the Dethlingen pollen record (Figure 2i) along with the presence of Ilex and Hedera [Koutsodendris et al., 2010]. Climatically, Buxus indicates mean summer temperatures above $17^{\circ} \mathrm{C}$ and all three taxa suggest prevalence of frostfree winters [Zagwijn, 1996; Aalbersberg and Litt, 1998]. Interestingly, Buxus pollen percentages at Dethlingen increase gradually during the younger parts of MIS 11c and peak closely before glacial inception, as also observed for Iberia (Figure 2h). The warming signal inferred by the expansion of Buxus at Dethlingen is also evident in other proxy records from continental Europe. Based on regional biostratigraphic correlations of terrestrial MIS 11c (i.e., Holsteinian) pollen records (Figure $\mathrm{S} 1$ in the supporting information) [Geyh and Müller, 2005, 2007; Koutsodendris et al., 2012], a synchronous spread of Buxus is documented across Central Europe from Poland to the British Isles during the youngest intervals of the interglacial. Considering the 15-16 ka long varve-based chronology of the MIS 11c pollen records from the lowlands of northern Germany (Munster-Breloh, Hetendorf, and Dethlingen) [Geyh and Müller, 2005, 2007; 

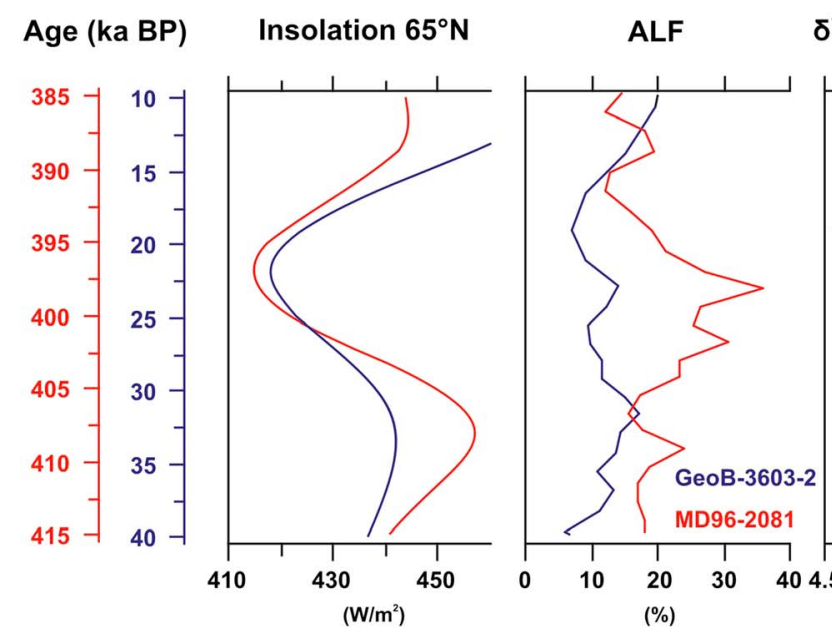

$\delta^{18} \mathrm{O}$ C. wuellerstorfi

Figure 6. Comparison of the summer insolation at $65^{\circ} \mathrm{N}$ [Berger and Loutre, 1991], the Agulhas leakage fauna (ALF) and the $\delta^{18} \mathrm{O}$ measured on $C$. wuellerstorfi between MIS 11 (red line; core MD96-2081) and the Last Glacial Maximum

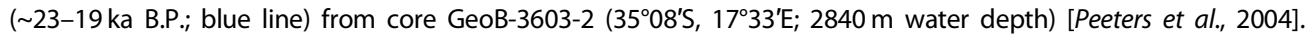

Koutsodendris et al., 2011, 2012], the Buxus expansion peaked $\sim 10-15 \mathrm{ka}$ after the onset of the interglacial forestation in Central Europe, i.e., at $\sim 400$ ka B.P. (Figure 2i). The expansion of Buxus indicates persistent warming in continental Europe during the end of MIS 11c. Independent support for such warming comes from paleolimnological data. The diatom Aulacoseira ambigua, which shows maximum growth rates under high-water temperatures $\left(18-23^{\circ} \mathrm{C}\right)$ [Shear et al., 1976], exhibits a pronounced percentage increase in the Dethlingen paleolake during the youngest interval of MIS 11c (Figure 2j) [Koutsodendris et al., 2013]. Clearly, A. ambigua percentages increase slightly earlier than Buxus (Figures $2 \mathrm{i}$ and $\mathrm{j}$ ); however, this lag can be attributed to the different ecological thresholds of biotic proxies [Lotter et al., 1995; Heegaard et al., 2006]. Hence, the abundance peaks of Buxus and A. ambigua unequivocally document prolonged warm conditions in both terrestrial and aquatic environments of continental Europe during the end of MIS 11c.

\subsection{Agulhas Leakage as Source for Prolonged MIS 11c Warmth in Europe}

The marine and terrestrial proxy records discussed above consistently suggest persistent warmth in the Northeast Atlantic and continental Europe during the end of MIS 11c ( 400-395 ka B.P.; Figure 2), closely before the onset of the next glaciation as marked by a series of cooling episodes in the North Atlantic (substage MIS 11b) [Martrat et al., 2007; Voelker and de Abreu, 2011]. Independent from the conservative handling of the age-model uncertainties via allowing a $\sim 2$ ka error, and hence potential leads and lags between the different proxy records, it is without any doubt that the 5 ka long warming paradoxically occurred during low insolation (below $\sim 430 \mathrm{~W} / \mathrm{m}^{-2}$; Figure 2a). This implies that orbital insolation forcing can be excluded as a cause. In contrast, the orbital configuration at that time should have led to cooler conditions as demonstrated by the $\mathrm{CH}_{4}$ and temperature decrease registered in Antarctica ice cores (Figures $2 \mathrm{~b}$ and $2 \mathrm{c}$ ) [Jouzel et al., 2007; Loulergue et al., 2008]. This contradiction becomes even more enigmatic considering that the summer insolation at the end of MIS 11c and during the Last Glacial Maximum ( 23-19 ka B.P.) was almost identical (Figure 6), but European climate was substantially different between the two periods [Martrat et al., 2007].

Conspicuously, however, the end of the MIS 11c interglacial is marked by strengthening of the Agulhas leakage in the South Atlantic (Figures 2d and 6) [Peeters et al., 2004; Dickson et al., 2010a, 2010b]. The reasons for this phase of exceptional Agulhas leakage strength are not clear. Recent modeling highlighted the sensitivity of the leakage to the strength and latitudinal position of the Southern Hemisphere midlatitude westerlies, which drive the surface ocean transports in the Southwest Indian subgyre [Durgadoo et al., 2013], thereby defining the water volume transports to the leakage area and ultimately, the leakage strength. Hence, the strong leakage at the end of MIS 11c was plausibly triggered by a strengthening and equatorial shifting of the westerlies consistent with the Southern Hemisphere atmospheric circulation response to Northern Hemisphere cooling [Lee et al., 2011] such as during the inception of cold conditions at the end of 
MIS 11c. Stronger westerlies would also be in line with a more rapid export of near-surface waters out of the SE Atlantic driven by a strengthened South Atlantic subtropical gyre circulation and concomitantly increased transports in the Benguela Current [Dickson et al., 2010a, 2010b]. Given the impact of Agulhas leakage on Atlantic circulation [Beal et al., 2011], we suggest that an interhemispheric teleconnection between strong leakage in the South Atlantic and AMOC-driven warmth in the North Atlantic maintained temperate conditions off Iberia and continental Europe, plausibly extending the duration of the MIS 11c climatic optimum. Our hypothesis is supported by benthic foraminiferal $\delta^{13} \mathrm{C}$ data, a widely used proxy for deep ocean ventilation and indirect indicator of AMOC strength, from the central North Atlantic (Site U1313), subpolar North Atlantic (ODP Site 980), and the Iberian margin (Site MD01-2446) that document a strong AMOC between 400 and 390 ka B.P. [Oppo et al., 1998; Voelker et al., 2010; Vázquez Riveiros et al., 2013]. Moreover, foraminifer-based and alkenone-based SST reconstructions from the North Atlantic provide evidence for AMOC-driven prolonged warmth beyond the end of the MIS 11c climate optimum along the NAC (ODP Sites 980 and U1313, core M23414) [McManus et al., 1999; Kandiano and Bauch, 2007; Stein et al., 2009] and the Gulf Stream (ODP Site 1058) [Billups et al., 2004].

Independent paleoclimatic evidence [Bard and Rickaby, 2009] supports the contention that MIS 11c was embedded in a series of extreme latitudinal STF migrations during the mid-Brunhes period that severely impacted the Agulhas leakage. Dynamically, these extreme STF changes diagnose likewise extreme changes in the southern westerly wind trajectories to which the leakage responds particularly sensitively [Durgadoo et al., 2013]. The transient leakage maximum at the end of MIS 11c hence is consistent with the increased input of wind energy as the STF, and associated westerlies started to migrate toward their northernmost position of the Late Pleistocene [Bard and Rickaby, 2009]. Strong Agulhas leakage could have then strengthened the AMOC, modulating the circum-North Atlantic interglacial climate during this period of weak insolation by enhancing the transport of warm tropical-subtropical waters across the North Atlantic to higher latitudes.

\section{Conclusions}

The comparison between the ALF record from the southern tip of Africa [Peeters et al., 2004] and marine and terrestrial data sets off Iberia [de Abreu et al., 2005; Desprat et al., 2005; Tzedakis et al., 2009] and Central Europe [Koutsodendris et al., 2010, 2013] indicates an interhemispheric teleconnection between enhanced Agulhas leakage in the South Atlantic and AMOC-driven warmth in the North Atlantic, which significantly affected climate and ecosystems in continental Europe. Considering the close analogies between the orbital configurations for MIS 11c and the Holocene [Loutre and Berger, 2003], and in light of the anthropogenically induced 2-4 Sverdrup Agulhas transport increase per decade since the 1960s [Biastoch et al., 2009; Rouault et al., 2009; Backeberg et al., 2012] that may further accelerate in the next century [Sen Gupta et al., 2009], such a modulation has important implications for the present and near-future climate beyond the humaninduced greenhouse gas forcing.

\section{Acknowledgments}

Pollen and diatom data from Dethlingen paleolake are available in Tables S1 and $\mathrm{S} 2$ in the supporting information, and are archived at www.pangaea.de. Ice core (EDC) and benthic $\delta^{18} \mathrm{O}$ (LR04) data sets were accessed at NOAA Climate Data Center (http://www.ncdc.noaa.gov/). We thank S. Desprat, H. Pälike, F. Peeters, and A. Voelker for providing data from cores MD96-2081, MD01-2443, and MD01-

2447. Discussions with A. Bahr, A. Brauer, O. Friedrich, and A. Lotter are gratefully acknowledged. This study was funded by the German Research Foundation (DFG).

\section{References}

Aalbersberg, G., and T. Litt (1998), Multiproxy climate reconstructions for the Eemian and Early Weichselian, J. Quat. Sci., 13, 367-390.

Backeberg, B. C., P. Penven, and M. Rouault (2012), Impact of intensified Indian Ocean winds on mesoscale variability in the Agulhas system, Nat. Clim. Change, 2, 608-612, doi:10.1038/nclimate1587.

Bard, E., and R. E. Rickaby (2009), Migration of the subtropical front as a modulator of glacial climate, Nature, 460, 380-383, doi:10.1038/ nature08189.

Bassinot, F. C., L. D. Labeyrie, E. Vincent, X. Quidelleur, N. J. Shackleton, and Y. Lancelot (1994), The astronomical theory of climate and the age of the Brunhes-Matuyama magnetic reversal, Earth Planet. Sci. Lett., 126, 91-108.

Beal, L. M., W. P. De Ruijter, A. Biastoch, and R. Zahn (2011), On the role of the Agulhas system in ocean circulation and climate, Nature, 472 , 429-436, doi:10.1038/nature09983.

Berger, A., and M. F. Loutre (1991), Insolation values for the climate of the last 10 million years, Quat. Sci. Rev., 10, $297-317$.

Biastoch, A., C. W. Boning, and J. R. Lutjeharms (2008), Agulhas leakage dynamics affects decadal variability in Atlantic overturning circulation, Nature, 456, 489-492, doi:10.1038/nature07426.

Biastoch, A., C. W. Boning, F. U. Schwarzkopf, and J. R. Lutjeharms (2009), Increase in Agulhas leakage due to poleward shift of Southern Hemisphere westerlies, Nature, 462, 495-498, doi:10.1038/nature08519.

Billups, K., W. Chaisson, M. Worsnopp, and R. Thunell (2004), Millennial-scale fluctuations in subtropical northwestern Atlantic surface ocean hydrography during the mid-Pleistocene, Paleoceanography, 19, PA2017, doi:10.1029/2003PA000990.

Birks, H. J. B. (1986), Late-Quaternary biotic changes in terrestrial and lacustrine environments, with particular reference to northwest Europe, in Handbook of Holocene Palaeoecology and Palaeohydrology, edited by B. E. Berglund, pp. 3-65, John Wiley, Chichester, U. K. 
Birks, H. J. B., and H. H. Birks (2004), The rise and fall of forests, Science, 305, 484-485, doi:10.1126/science.1101357.

Caley, T., J. Giraudeau, B. Malaizé, L. Rossignol, and C. Pierre (2012), Agulhas leakage as a key process in the modes of Quaternary climate changes, Proc. Natl. Acad. Sci. U.S.A., 109, 6835-6839, doi:10.1073/pnas.1115545109.

Cortese, G., A. Abelmann, and R. Gersonde (2007), The last five glacial-interglacial transitions: A high-resolution 450,000-year record from the subantarctic Atlantic, Paleoceanography, 22, PA4203, doi:10.1029/2007PA001457.

de Abreu, L., F. F. Abrantes, N. J. Shackleton, P. C. Tzedakis, J. F. McManus, D. W. Oppo, and M. A. Hall (2005), Ocean climate variability in the eastern North Atlantic during interglacial marine isotope stage 11: A partial analogue to the Holocene?, Paleoceanography, 20, PA3009, doi:10.1029/2004PA001091.

de Beaulieu, J. L., V. Andrieu-Ponel, M. Reille, E. Grüger, P. C. Tzedakis, and H. Svobodova (2001), An attempt at correlation between the Velay pollen sequence and the Middle Pleistocene stratigraphy from central Europe, Quat. Sci. Rev., 20, 1593-1602.

Desprat, S., M. F. Sánchez Goñi, J. L. Turon, J. F. McManus, M. F. Loutre, J. Duprat, B. Malaizé, O. Peyron, and J. P. Peypouquet (2005), Is vegetation responsible for glacial inception during periods of muted insolation changes?, Quat. Sci. Rev., 24, 1361-1374, doi:10.1016/ j.quascirev.2005.01.005.

Dickson, A. J., M. J. Leng, M. A. Maslin, and U. Röhl (2010a), Oceanic, atmospheric and ice-sheet forcing of South East Atlantic Ocean productivity and South African monsoon intensity during MIS-12 to 10, Quat. Sci. Rev., 29, 3936-3947, doi:10.1016/j.quascirev.2010.09.014.

Dickson, A. J., M. J. Leng, M. A. Maslin, H. J. Sloane, J. Green, J. A. Bendle, E. L. McClymont, and R. D. Pancost (2010b), Atlantic overturning circulation and Agulhas leakage influences on southeast Atlantic upper ocean hydrography during marine isotope stage 11, Paleoceanography, 25, PA3208, doi:10.1029/2009PA001830.

Durgadoo, J. V., B. R. Loveday, C. J. C. Reason, P. Penven, and A. Biastoch (2013), Agulhas leakage predominantly responds to the Southern Hemisphere westerlies, J. Phys. Oceanogr., 43, 2113-2131, doi:10.1175/jpo-d-13-047.1.

Fletcher, W. J., M. F. Sanchez Goñi, O. Peyron, and I. Dormoy (2010), Abrupt climate changes of the last deglaciation detected in a Western Mediterranean forest record, Clim. Past, 6, 245-264.

Geyh, M. A., and H. Müller (2005), Numerical ${ }^{230} \mathrm{Th} / \mathrm{U}$ dating and a palynological review of the Holsteinian/Hoxnian Interglacial, Quat. Sci. Rev., 24, 1861-1872, doi:10.1016/j.quascirev.2005.01.007.

Geyh, M. A., and H. Müller (2007), Palynological and geochronological study of the Holsteinian/Hoxnian/Landos interglacial, in The Climate of Past Interglacials, Developments in Quaternary Science, vol. 7, edited by F. Sirocko et al., pp. 387-396, Elsevier, Amsterdam.

Heegaard, E., A. F. Lotter, and H. J. B. Birks (2006), Aquatic biota and the detection of climate change: Are there consistent aquatic ecotones? J. Paleolimnol., 35, 507-518, doi:10.1007/s10933-005-3239-x.

Jouzel, J., et al. (2007), Orbital and millennial Antarctic climate variability over the past 800,000 years, Science, 317, 793-796, doi:10.1126/ science. 1141038

Kandiano, E. S., and H. A. Bauch (2007), Phase relationship and surface water mass change in the Northeast Atlantic during marine isotope stage 11 (MIS 11), Quat. Res., 68, 445-455, doi:10.1016/j.yqres.2007.07.009.

Koutsodendris, A., U. C. Müller, J. Pross, A. Brauer, U. Kotthoff, and A. F. Lotter (2010), Vegetation dynamics and climate variability during the Holsteinian interglacial based on a pollen record from Dethlingen (northern Germany), Quat. Sci. Rev., 29, 3298-3307, doi:10.1016/ j.quascirev.2010.07.024

Koutsodendris, A., A. Brauer, H. Pälike, U. C. Müller, P. Dulski, A. F. Lotter, and J. Pross (2011), Sub-decadal- to decadal-scale climate cyclicity during the Holsteinian interglacial (MIS 11) evidenced in annually laminated sediments, Clim. Past, 7, 987-999, doi:10.5194/cp-7-987-2011.

Koutsodendris, A., J. Pross, U. C. Müller, A. Brauer, W. J. Fletcher, N. Kühl, E. Kirilova, F. T. M. Verhagen, A. Lücke, and A. F. Lotter (2012), A shortterm climate oscillation during the Holsteinian interglacial (MIS 11c): An analogy to the 8.2 ka climatic event?, Global Planet. Change, 92/93, 224-235, doi:10.1016/j.gloplacha.2012.05.011.

Koutsodendris, A., A. F. Lotter, E. Kirilova, F. T. M. Verhagen, A. Brauer, and J. Pross (2013), Evolution of a Holsteinian (MIS 11c) palaeolake based on a 12-ka-long diatom record from Dethlingen (northern Germany), Boreas, 42, 714-728, doi:10.1111/bor.12001.

Leduc, G., R. Schneider, J. H. Kim, and G. Lohmann (2010), Holocene and Eemian sea surface temperature trends as revealed by alkenone and Mg/Ca paleothermometry, Quat. Sci. Rev., 29, 989-1004, doi:10.1016/j.quascirev.2010.01.004.

Lee, S.-Y., J. C. H. Chiang, K. Matsumoto, and K. S. Tokos (2011), Southern Ocean wind response to North Atlantic cooling and the rise in atmospheric $\mathrm{CO}_{2}$ : Modeling perspective and paleoceanographic implications, Paleoceanography, 26, PA1214, doi:10.1029/2010PA002004

Lisiecki, L. E., and M. E. Raymo (2005), A Pliocene-Pleistocene stack of 57 globally distributed benthic $\delta{ }^{18}$ O records, Paleoceanography, 20 , PA1003, doi:10.1029/2004PA001071.

Lotter, A. F., H. J. B. Birks, and B. Zolitschka (1995), Late-glacial pollen and diatom changes in response to two different environmental perturbations: Volcanic eruption and Younger Dryas cooling, J. Paleolimnol., 14, $23-47$.

Loulergue, L., A. Schilt, R. Spahni, V. Masson-Delmotte, T. Blunier, B. Lemieux, J. M. Barnola, D. Raynaud, T. F. Stocker, and J. Chappellaz (2008), Orbital and millennial-scale features of atmospheric $\mathrm{CH}_{4}$ over the past 800,000 years, Nature, 453, 383-386, doi:10.1038/nature06950

Loutre, M. F., and A. Berger (2003), Marine isotope stage 11 as an analogue for the present interglacial, Global Planet. Change, 36, 209-217, doi:10.1016/s0921-8181(02)00186-8.

Lutjeharms, J. R. E. (2006), The Agulhas Current, Springer, Berlin.

Marino, G., R. Zahn, M. Ziegler, C. Purcell, G. Knorr, I. R. Hall, P. Ziveri, and H. Elderfield (2013), Agulhas salt-leakage oscillations during abrupt climate changes of the Late Pleistocene, Paleoceanography, 28, 599-606, doi:10.1002/palo.20038.

Martínez-Méndez, G., R. Zahn, I. R. Hall, F. J. C. Peeters, L. D. Pena, I. Cacho, and C. Negre (2010), Contrasting multiproxy reconstructions of surface ocean hydrography in the Agulhas Corridor and implications for the Agulhas Leakage during the last 345,000 years, Paleoceanography, 25, PA4227, doi:10.1029/2009PA001879.

Martrat, B., J. O. Grimalt, N. J. Shackleton, L. de Abreu, M. A. Hutterli, and T. F. Stocker (2007), Four climate cycles of recurring deep and surface water destabilizations on the Iberian margin, Science, 317, 502-507, doi:10.1126/science.1139994.

McManus, J. F., D. W. Oppo, and J. L. Cullen (1999), A 0.5-million-year record of millennial-scale climate variability in the North Atlantic, Science, 283, 971-975, doi:10.1126/science.283.5404.971.

Müller, U. C., and J. Pross (2007), Lesson from the past: Present insolation minimum holds potential for glacial inception, Quat. Sci. Rev., 26, 3025-3029, doi:10.1016/j.quascirev.2007.10.006.

Naughton, F., M. F. Sanchez Goñi, S. Desprat, J. L. Turon, J. Duprat, B. Malaizé, C. Joli, E. Cortijo, T. Drago, and M. C. Freitas (2007), Present-day and past (last 25000 years) marine pollen signal off western Iberia, Mar. Micropaleontol., 62, 91-114, doi:10.1016/j.marmicro.2006.07.006

Oppo, D. W., J. F. McManus, and J. L. Cullen (1998), Abrupt climate events 500,000 to 340,000 years ago: Evidence from subpolar North Atlantic sediments, Science, 279, 1335-1338, doi:10.1126/science.279.5355.1335.

Paillard, D., L. Labeyrie, and P. Yiou (1996), Macintosh program performs time-series analysis, Eos Trans. AGU, 77, 379, doi:10.1029/ $96 \mathrm{EO} 00259$. 
Palumbo, E., J. A. Flores, C. Perugia, Z. Petrillo, A. H. L. Voelker, and F. O. Amore (2013), Millennial scale coccolithophore paleoproductivity and surface water changes between 445 and $360 \mathrm{ka}$ (marine isotope stages 12/11) in the Northeast Atlantic, Palaeogeogr. Palaeoclimatol. Palaeoecol., 383-384, 27-41, doi:10.1016/j.palaeo.2013.04.024.

Parrenin, F., et al. (2007), The EDC3 chronology for the EPICA Dome C ice core, Clim. Past, 3, 485-497, doi:10.5194/cp-3-485-2007.

Peeters, F. J. C., R. Acheson, G.-J. A. Brummer, W. P. M. de Ruijter, R. R. Schneider, G. Ganssen, E. Ufkes, and D. Kroon (2004), Vigorous exchange between the Indian and Atlantic oceans at the end of the past five glacial periods, Nature, 430, 661-665.

Preece, R. C., et al. (2007), Terrestrial environments during MIS 11: Evidence from the Palaeolithic site at West Stow, Suffolk, UK, Quat. Sci. Rev., 26, 1236-1300, doi:10.1016/j.quascirev.2006.11.016.

Rodrigues, T., A. H. L. Voelker, J. O. Grimalt, F. Abrantes, and F. Naughton (2011), Iberian Margin sea surface temperature during MIS 15 to 9 (580-300 ka): Glacial suborbital variability versus interglacial stability, Paleoceanography, 26, PA1204, doi:10.1029/2010PA001927.

Rouault, M., P. Penven, and B. Pohl (2009), Warming in the Agulhas Current system since the 1980's, Geophys. Res. Lett., 36, L12602, doi:10.1029/2009GL037987.

Schneider, B., G. Leduc, and W. Park (2010), Disentangling seasonal signals in Holocene climate trends by satellite-model-proxy integration, Paleoceanography, 25, PA4217, doi:10.1029/2009PA001893.

Sen Gupta, A., A. Santoso, A. S. Taschetto, C. C. Ummenhofer, J. Trevena, and M. H. England (2009), Projected changes to the Southern Hemisphere ocean and sea ice in the IPCC AR4 climate models, J. Clim., 22, 3047-3078, doi:10.1175/2008jcli2827.1.

Shear, H., C. Nalewajko, and H. M. Bacchus (1976), Some aspects of the ecology of Melosira spp. in Ontario Lakes, Hydrobiologia, 50, 173-176.

Stein, R., J. Hefter, J. Grützner, A. Voelker, and B. D. A. Naafs (2009), Variability of surface water characteristics and Heinrich-like events in the Pleistocene midlatitude North Atlantic Ocean: Biomarker and XRD records from IODP Site U1313 (MIS 16-9), Paleoceanography, 24, PA2203, doi:10.1029/2008PA001639.

Tzedakis, P. C. (2010), The MIS 11-MIS 1 analogy, southern European vegetation, atmospheric methane and the "early anthropogenic hypothesis", Clim. Past, 6, 131-144, doi:10.5194/cp-6-131-2010.

Tzedakis, P. C., H. Pälike, K. H. Roucoux, and L. de Abreu (2009), Atmospheric methane, southern European vegetation and low-mid latitude links on orbital and millennial timescales, Earth Planet. Sci. Lett., 277, 307-317, doi:10.1016/j.epsl.2008.10.027.

Tzedakis, P. C., E. W. Wolff, L. C. Skinner, V. Brovkin, D. A. Hodell, J. F. McManus, and D. Raynaud (2012), Can we predict the duration of an interglacial?, Clim. Past, 8, 1473-1485, doi:10.5194/cp-8-1473-2012.

van Sebille, E., P. J. van Leeuwen, A. Biastoch, and W. P. M. de Ruijter (2010), On the fast decay of Agulhas rings, J. Geophys. Res., 115, C03010, doi:10.1029/2009JC005585.

Vázquez Riveiros, N., C. Waelbroeck, L. Skinner, J.-C. Duplessy, J. F. McManus, E. S. Kandiano, and H. A. Bauch (2013), The "MIS 11 paradox" and ocean circulation: Role of millennial scale events, Earth Planet. Sci. Lett., 371-372, 258-268, doi:10.1016/j.epsl.2013.03.036.

Voelker, A. H. L., and L. de Abreu (2011), A review of abrupt climate change events in the Northeastern Atlantic Ocean (Iberian Margin): Latitudinal, longitudinal and vertical gradients, in Abrupt Climate Change: Mechanisms, Patterns and Impacts, Geophys. Monogr. Ser., vol. 193, edited by H. Rashid et al., pp. 15-37, AGU, Washington, D. C.

Voelker, A. H. L., T. Rodrigues, K. Billups, D. Oppo, J. McManus, R. Stein, J. Hefter, and J. O. Grimalt (2010), Variations in mid-latitude North Atlantic surface water properties during the mid-Brunhes (MIS 9-14) and their implications for the thermohaline circulation, Clim. Past, 6 , 531-552, doi:10.5194/cp-6-531-2010.

Wardle, D. A., L. R. Walker, and R. D. Bardgett (2004), Ecosystem properties and forest decline in contrasting long-term chronosequences, Science, 305, 509-513, doi:10.1126/science.1098778.

Zagwijn, W. H. (1996), An analysis of Eemian climate in western and central Europe, Quat. Sci. Rev., 15, 451-469. 